\title{
FURTHER NOTES ON BIRDS AND MAMMALS OF THE CARIBOU MOUNTAINS, ALBERTA
}

E. OTTO HÖHN, Dept. of Physiology, University of Alberta, Edmonton, Alta. RODNEY D. BURNS, Provincial Museum of Alberta, Edmonton, Alta.

In the hope of obtaining proof of local nesting of three bird species of special interest previously found in this area, namely the Red-throated Loon, Northern Phalarope and Graycheeked Thrush, we made another visit June 18 to 25,1975 , to the eastern part of Margaret Lake (the largest lake of the area, lying west of Eva Lake and erroneously not labelled on the sketch map in our earlier publication, Blue Jay 1975, 33: 74) and to Rock Island Lake. E.O.H. revisited one lake on July 24 and 25 . The account below is restricted to further notes on these species, species not recorded earlier (4 birds and 1 mammal) and notes which modify our earlier account of the local status of a few others.

\section{BIRDS}

Red-throated Loon: Earlier observations suggested that a few pairs of these loons were breeding near Rock Island Lake; this year's investigation added similar data from the eastern part of Margaret Lake, thus enlarging the apparent local nesting range. Two of these loons, which kept together as if paired, occupied a small lake near the mouth of the creek which drains Rock Island Lake into Margaret Lake throughout our stay here, June 18 to 22. On the evening of the first day, a third loon of this species arrived and swam up to the couple. All three performed what appeared to be a greeting ceremony, swimming close together with beaks pointed down at an angle of $45^{\circ}$; then one or, possibly, both members of the couple rushed at the invader, which escaped by diving. After this, for the hour we watched whenever the intruder surfaced, it was approached and attacked by one of the couple. By next morning the third loon had disappeared. Though we walked all around the shore of this small lake, no nest was found. When E.O.H. revisited it on July 24 there were still two Red-throated Loons idly floating about close together. A check of the most likely part of the shoreline for a nest failed to reveal one and the undisturbed behaviour of the birds made it very unlikely that they had a nest. This may have been a late nesting pair. Nero (1963, Birds of the Lake Athabasca Region, Saskatchewan) found fresh eggs as late as August 3 at about the same latitude in northern Saskatchewan. An attempt to check the site once more in early October for young was foiled by weather conditions on the plateau which precluded flying.

One other Red-throated Loon was seen on July 24 leaving the eastern point of Margaret Lake ( 7 miles east of the small lake referred to above) flying in a northerly direction with a fish in its beak.

Shoveler: Two males were seen by R.D.B. on Margaret Lake on June 20.

Scaup (? species): As in previous years, Scaup of which we obtained good views in flight seemed to both of us to have the wing patterns of the Greater Scaup. One egg from a nest of nine found on a creek draining into Margaret Lake on June 18 measured $61 \times 41 \mathrm{~mm}$. Bent (Life Histories of North American Wildfowl, part 1, 1923) gives $62.4 \times 43.7$ as the average dimensions of Greater Scaup eggs with extremes of $68.5 \times 44,59 \times 48$ and $54.5 \times$ 41.5 and $66.3 \times 40.7$; for Lesser Scaup 
average dimensions were $57.1 \times 39.7$ with extremes of $61.5 \times 38,59 \times 42.5$ and $50 \times 35.5$. Hence the egg we found is much more likely to have been that of a Greater than a Lesser Scaup.

It is thus likely, but further evidence is required, that Greater Scaup breed in the Caribou Mountains. It should also be pointed out that the identification of Lesser Scaup which we previously reported in this area was simply based on probability, in accord with current knowledge of the status of the two species in Alberta. It may ultimately be found that only Greater Scaup breed in the Caribou Mountains.

Old Squaw: R.D.B. saw a male on a small lake west of Rock Island Lake on June 23. The next day E.O.H., while approaching another small lake a little over a mile from the first, heard the spring call of a male and then saw the bird on the water. Both males were in rather discoloured breeding plumage, so our sightings may have been of one and the same bird. This second June sighting within 3 years suggests that local summering of nonbreeders is not as exceptional as we believed in 1973. The species occurs regularly as a spring migrant on Lake Athabasca and probably overflies the Caribou Mountains on spring migration.

Marsh Hawk: A female was seen at Rock Island Lake on June 24.

Sora: The characteristic descending whinnying call of this species was heard repeatedly during our stay near the mouth of the creek which drains Rock Island into Margaret Lake, June 18 to 21 .

Common Snipe: Not as local as our previous account suggests; breeds. Seen this year on the smaller lakes between Margaret and Eva Lakes as well as on Rock Island Lake and heard drumming near Margaret Lake. One flushed at Rock Island Lake on June 23 acted as if it had young. At one of the first-mentioned sites an adult was flushed from a downy young on July 24.
Northern Phalarope: When the small lake where a Northern Phalarope had been found in June, 1973, was revisited on June 22 and 23 , a phalarope of this species, judged to be a male, was seen on both days. Like the 1973 bird it showed intense anxiety at the observer's presence along a zone of some 250 yards of marshy foreshore. This particular lake has a more extensive marshy edge than other small lakes we visited and appears to be a breeding site of this species.

Herring Gull: R.D.B. found 9 nests, some with eggs and some with chicks on a visit to the small nesting colony on Rock Island Lake on June 22.

Alder Flycatcher: Seen in June in areas additional to those we recorded earlier, namely near Margaret Lake about 8 miles west of where they were heard in another year and at Rock Island Lake.

Barn Swallow: A nest with young was found in one of the buildings at Margaret Lake Fish Camp on July 24. Probably the swallows seen there in 1973 were also breeding.

Gray-cheeked Thrush: Much scarcer in June than in the same month in 1973. Only one, with food in its beak, was seen, though a few others were heard singing, all near Rock Island Lake.

Yellowthroat: Two heard singing in June, 8 miles from where previously recorded; evidently less local than we believed.

Blackpoll Warbler: A nest with five eggs was found June 19 near Margaret Lake. It was in a small dead spruce about 8 inches above the ground.

Bohemian Waxwing: An apparent pair near Margaret Lake, June 21: three or more near this area on July 23.

Cedar Waxwing: Two briefly perched on alders near our Rock Island Lake camp on June 24 .

\section{MAMMALS}

Several Heather and Gapper's Redbacked Voles were again trapped at Rock Island Lake in June as well as a Meadow Vole. The last-mentioned 
species is evidently not as local as our previous account suggested.

Short-tailed Weasel: On July 24 E.O.H. had a brief view of the rear half of one disappearing under one of the buildings at the Margaret Lake Fish
Camp. As its black tail tip was clearly seen it could not have been a Least Weasel and the area is well beyond the range of the Long-tailed Weasel.

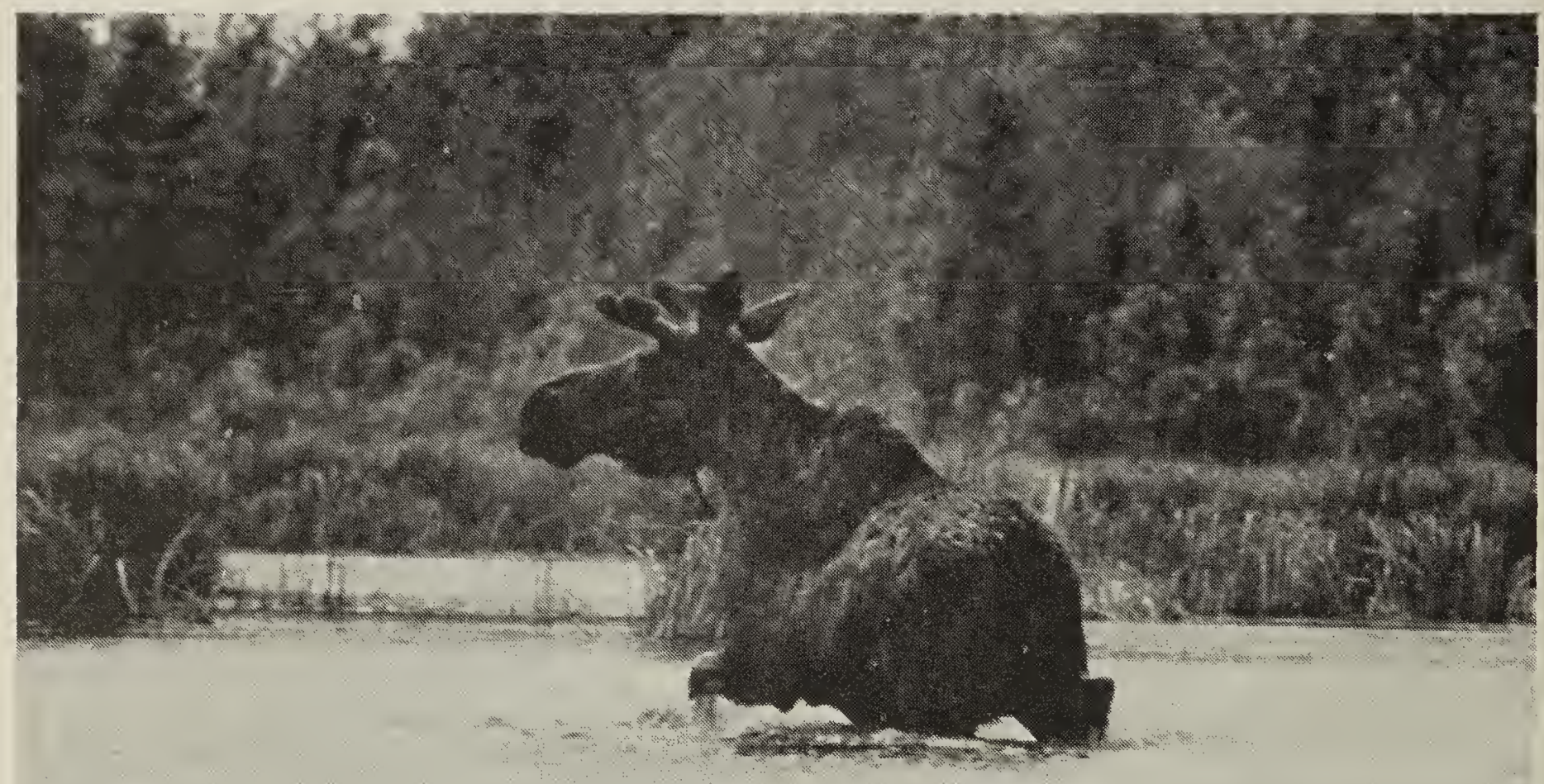

\section{SASKATCHEWAN CHRISTMAS MAMMAL COUNT - 1975}

Compiled by WAYNE C. HARRIS, Box 93, Raymore, Sask., S0A 3 J0.

Mild weather resulted in excellent coverage of the province, with 28 localities reporting, compared to only 16 last year. The number of species was also up from 15 species last year to 23 species this year. Counts taken in or near the forest edge resulted in several new species (Gray Wolf, Moose, and Woodland Caribou). Unusual was a
Franklin's Ground Squirrel (a species which normally hibernates), seen near Asquith. The warm weather may account for this.

Populations in general appear to be remaining rather stable, with possibly the exception of the Lynx. This year it was reported only once, compared to two last year, and the coverage this 